\title{
Efektifitas Standar Prosedur Operasional Terhadap Penurunan Waktu Tunggu Operasi Elektif di Rumah Sakit Umum
}

\author{
Fransiska Leny Aweq*, Nono Ifantono, Lukman Hakim
}

* Korespondensi Penulis: fransiskaleny91@gmail.com

* RSIA Puri Bunda, Malang, Jawa Timur, Indonesia

\begin{tabular}{ll}
\hline INDEXING & $\begin{array}{l}\text { A B S T R A C T } \\
\text { Keywords: }\end{array}$ This research used quasi-experimental design with pre and post test design. Then, for the method \\
Time management; & used in this research was pre and post intervention which analyze the primer data and secondary \\
post the standard operating procedure was socialized. This research used 52 people as the sample. & The research about waiting time of elective surgery and find the main problem bring in the chosen \\
& solution by the researcher which is this solution showed the result of the comparison in pre and \\
post socialization the standard operating procedure that increase about 25\%. This comparison \\
showed that there is enhancement of the number of staffs in operating room who could \\
performance the surgery on time and also showed the reduction number of waiting time in elective \\
surgery.
\end{tabular}

Kata kunci:

Waktu tunggu;

Manajemen waktu;
Desain penelitian ini menggunakan kuasi eksperimental dengan jenis satu kelompok pre dan post test desain. Metode penelitian adalah pre dan post intervention dengan analisa data primer dan data sekunder serta pendekatan deskriptif membandingkan hasil pre dan post sosialisasi SPO manajemen waktu staf kamar operasi. Jumlah sampel yang digunakan dalam penelitian ini adalah 52 orang. Penelitian mengenai waktu tunggu opersi elektif serta prioritas akar masalah dan solusi yang terpilih mendapatkan hasil implementasi berdasarkan perbandingan pre dan post sosialisasi sebesar $25 \%$, hal ini mengungkapkan bahwa terdapat peningkatan angka tidak terlambat staf OK dan terdapat penurunan waktu tunggu operasi elektif.

(C) 2017 JMMR. All rights reserved

$\overline{\text { Article history: received } 26 \text { A }}$ pr 2017; revised 15 May 2017; accepted 25 July 2017

\section{PENDAHULUAN}

Rumah Sakit Umum Karsa Husada merupakan rumah sakit kelas C milik Pemerintah Propinsi Jawa Timur dengan kapasitas 133 tempat tidur yang berdiri sejak tahun 1912 dan beralamat di Jalan Ahmad Yani No. 10-13 Batu. RSU Karsa Husada Batu telah terakreditasi penuh dengan lima pelayanan dasar pada tanggal 14 September 2011. Saat ini RSU Karsa Husada Batu memiliki staf berjumlah 307 orang. Saat ini RSU Karsa Husada menyediakan beberapa pelayanan antara lain: pelayanan rawat jalan, rawat inap, Pelayanan Bedah (Bedah Sentral, Bedah Tulang, Bedah Digestive, Bedah Urologi, Bedah Plastik dan Bedah Kandungan dan Kebidanan), Pelayanan Instalasi Gawat Darurat 24 Jam, Pelayanan Radiologi, Pelayanan Laboratorium, Pelayanan Instalasi Farmasi 24 Jam, Pelayanan Ambulance, Pemeliharaan Sarana Alat Medik, Pemeliharaan Sarana (Air bersih, Listrik dan Genset), Pelayanan Laundry, Pelayanan CSSD, Pelayanan Pemulasaran Jenazah, dan Pelayanan ICU (Intensive Care Unit).
Data tingkat efisiensi RSU Karsa Husada tahun 2015 dapat diketahui melalui data berikut: Bed Occupancy Ratio (BOR) 40,82 \% (Standar 60-85\%), Turn Over Interval (TOI) 5,13 (standar 1-3 hari), Bed Turn Over (BTO) 42,19 kali (standar 40-50 kali), Average Length of Stay (ALOS) 3,42 hari (standar 6-9 hari), Gross Death Rate (GDR) mencapai 51,63 \%o (standar $\leq 45 \%$ ), Net Death Rate (NDR) mencapai 23,57\%o (standar $<25 \%$ ).

Sumber daya manusia Instalasi Kamar Operasi RSU Karsa Husada berjumlah 21 orang yang terdiri dari : dokter spesialis obgyn 2 (dua) orang, dokter spesialis bedah 2 (dua) orang, dokter spesialis urologi 1 (satu) orang, dokter spesialis bedah plastik 1 (satu) orang, dokter spesialis digestive 1 (satu), dokter spesialis mata 2 (dua) orang, dokter spesialis ortopedi 2 (dua) orang dan dokter spesialis THT 2 (dua) orang, perawat bedah 6 (enam) orang, perawat anastesi 2 (dua) orang dan administrasi 1 (satu) orang.

Rumah sakit dalam memberikan pelayanan kepada masayarakat memiliki peran yang sangat strategis dalam meningkatkan derajat kesehatan masyarakat. Pelayanan yang diberikan kepada masyarakat harus bermutu dan 
sesuai dengan standar pelayanan rumah sakit. Pelayanan instalasi kamar operasi merupakan salah satu bagian dari pelayanan penunjang medis di Rumah Sakit yang melaksanakan kegiatan pembedahan setiap harinya berdasarkan penjadwalan yang telah disepakati. ${ }^{1}$

Untuk meningkatkan standar mutu pelayanan instalasi kamar operasi maka diperlukan strategi untuk mengatur jadwal dan standar prosedur operasional . Jadwal operasi yang buruk juga akan berpengaruh terhadap angka waiting time dan overtime. Salah satu penyebab angka waiting time yang tinggi adalah penggunaan jadwal kamar operasi tidak efisien, keterlambatan staf kamar operasi yang dapat mengakibatkan perubahan jadwal berikutnya dengan waiting time pasien bertambah hal ini dapat berpengaruh pada kondisi kesehatan pasien dan tingkat kepuasan pasien terhadap layanan rumah sakit. Angka overtime, dalam hal ini overtime perawat petugas operasi (dokter, perawat, anestesi) yang tinggi juga akan berpengaruh terhadap performa dari layanan yang diberikan, biaya overtime (lembur) dan tingkat kepuasan petugas operasi. Dengan permasalahan tersebut, dibutuhkan sebuah penjadwalan yang efektif untuk meningkatkan reputasi dan performa rumah sakit. $^{3}$

Sistem jadwal operasi elektif di Instalasi Kamar Operasi RSU Karsa Husada adalah jadwal setiap operasi elektif yang akan dilaksanakan diberikan satu hari sebelum operasi dengan batas waktu pemesanan jadwal kamar operasi elektif jam 13.00 oleh staf yang ada di ruangan rawat inap dan poli. Berdasarkan kebijakan RSU Karsa Husada, waktu pelayanan operasi elektif dimulai dari 07.00 pagi - 15.30 siang, dengan induksi pertama dilakukan jam 7.45 dan induksi terakhir jam 13.00 siang. Dalam hal ini, usaha-usaha untuk meningkatkan efisiensi dalam penggunaan ruang operasi menjadi suatu hal penting. Maka dari itu, diperlukan operating room management yang baik untuk memaksimalkan utilitas dari sumber sumber daya dan fasilitas yang ada. Salah satu bagian penting dalam operating room management adalah penjadwalan ruang operasi (operating room scheduling), menjalankan standar prosedur operasional manajemen waktu kamar operasi sehingga tidak terjadinya keterlambatan dan penundaan operasi elektif. Penjadwalan ruang operasi yang baik akan membantu rumah sakit dalam mengatur ruang operasi menjadi efisien dengan cara menerapkan dan mematuhi standar prosedur operasional yang ada di kamar operasi. ${ }^{2}$

\section{METODE PENELITIAN}

Metode yang digunakan dalam proses identifikasi masalah adalah observasi, wawancara, analisis laporan tahunan dan SPM (standar pelayanan minimal) serta melakukan FGD (Focus Group Discussion) dengan pihak Rumah sakit menggunakan metode scoring USG (Urgency, Seriousness, Growth) untuk mendapatkan prioritas akar masalah dan solusi.

Penelitian ini dilakukan dengan metode deskriptif dengan data yang didapatkan dari data primer dan sekunder sehingga menghasilkan data yang akan dianalisis untuk menentukan perhitungan manajemen waktu staf kamar operasi dengan membandingkan pre sosialisasi dan post sosialisasi dari solusi yang akan diterapkan. Data primer didapatkan melalui observasi aktivitas staf kamar operasi dengan mengamati time motion study khusus pada bedah umum dengan kasus soft tissue tumor dan hernia. Data sekunder didapatkan melalui data laporan operasi setiap hari pada bulan September dan oktober tahun 2016. Jumlah sampel yang digunakan dalam penelitian ini adalah 52 orang.

\section{HASIL DAN PEMBAHASAN}

Dalam penelitian ini setelah menganalisis data primer dan data sekunder ditemukan standar pelayanan minimal rumah sakit yang belum mencapai standar. Untuk mengidentifikasi masalah dan menentukan prioritas masalah dilakukan FGD (focus group discussion) dengan menggunakan metode USG (Urgency, Seriousness, Growth). Prioritas masalah yang terpilih adalah waktu tunggu operasi elektif yang belum mencapai standar pelayanan minimal RSU Karsa Husada. Selanjutnya dari prioritas masalah yang terpilih, dilakukan FGD untuk mengidentifikasi akar masalah dalam mengetahui faktor terbesar penyebab akar masalah tersebut dengan menggunakan diagram fishbone dan metode USG. Hasil identifikasi akar masalah yang terpilih dari proses FGD tersebut adalah manajemen waktu staf kamar operasi.

Setelah akar permasalah terpilih dilakukan pemilihan solusi. Terdapat tiga alternatif solusi, yaitu membuat SPO mengenai manajemen waktu staf $\mathrm{OK}$, jadwal operasi diberikan satu hari sebelum operasi dan konsekuensi kepada staf kamar operasi yang terlambat 15 menit. Pemilihan alternatif solusi ini berdasarkan efektifitas, efisiensi dan mudah dilaksanakan oleh pihak rumah sakit terutama di Instalasi Kamar Operasi RSU Karsa Husada. 
Dari hasil FGD solusi yang dapat dijalankan oleh peneliti adalah membuat SPO manajemen waktu staf OK.

Hasil prioritas solusi yang telah ditetapkan, peneliti membuat SPO mengenai manajemen waktu staf OK dan disosialisasikan kepada semua staf yang ada di kamar operasi. Selanjutnya setelah sosialisasi peneliti mengambil sampel pre dan post sosialisasi SPO untuk evaluasi mengenai manajemen staf kamar operasi.

Dampak sosialisasi dilihat dengan membandingkan hasil pre sosialisasi yaitu data laporan operasi bulan September 2016, dengan hasil post sosialisasi yaitu data laporan operasi bulan oktober 2016. Target sosialisasi adalah adanya peningkatan pemanfaatan kamar operasi dengan efisien sehingga tidak terjadi penundaan operasi elektif dan mempercepat waktu tunggu operasi elektif pasien di Rumah Sakit Umum Karsa Husada.

Dari hasil uji SPSS Paired Samples Test dengan standar signifikan jika $\mathrm{P}<0,05$, hasil yang didapatkan pre sosialisasi dan post sosialisasi adalah $\mathrm{P}=0,04$ menunjukan hasil yang signifikan. Hal ini mengungkapkan bahwa ada hubungan yang signifikan terhadap keterlambatan staf kamar operasi dengan penerapan peraturan standar prosedur operasional kamar operasi.

Hasil pre sosialisasi menunjukan persentase angka terlambatan staf kamar operasi adalah $87,50 \%$ sedangkan persentase angka tidak terlambat staf kamar operasi adalah $12,50 \%$. Hal ini menunjukan bahwa angka ketelambatan staf kamar operasi masih tinggi.

Gambar 1. Persentase Pre Sosialisasi SPO.

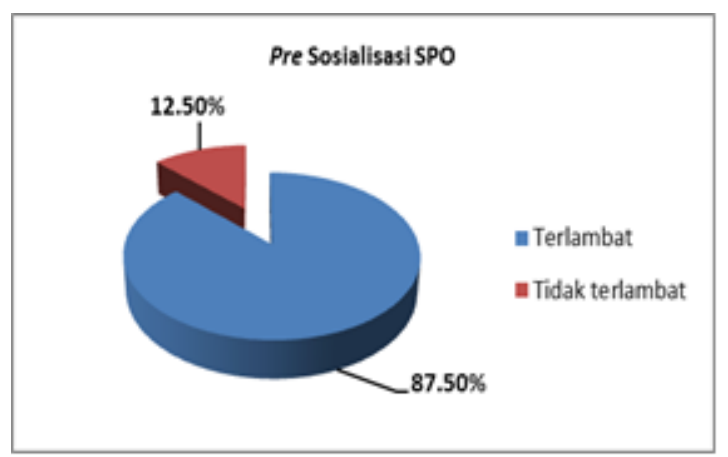

Sumber: data primer dan sekunder laporan operasi bulan September dan oktober 2016
Gambar 2. Persentase Post Sosialisasi SPO

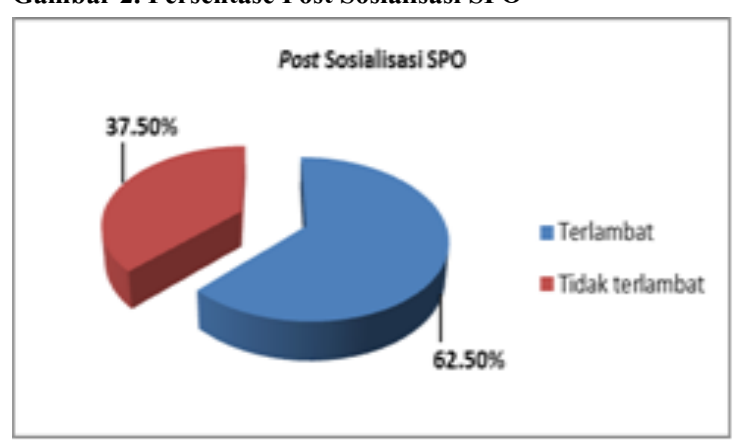

Sumber: data primer dan sekunder laporan operasi bulan September dan oktober 2016

Dalam melakukan sosialisasi dan implementasi standar prosedur operasional manajemen waktu staf kamar operasi yang telah dilaksakan dan dibandingkan pre dan post sosialisasi menunjukan hasil cukup bermakna, yaitu penurunan angka keterlambatan dan peningkatan angka tidak terlambat staf kamar operasi dengan hasil perbandingan pada gambar 3. Perbandingan pre dan post sosialisasi SPO manajemen waktu staf OK.

\section{Gambar 3. Perbandingan pre dan post SPO}

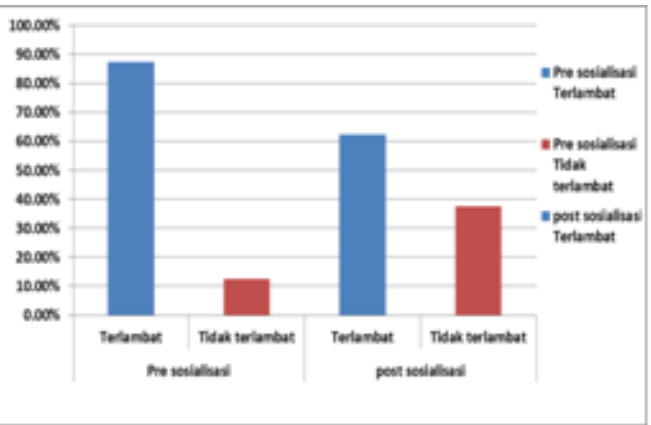

Gambar 4. Hasil Uji T-test

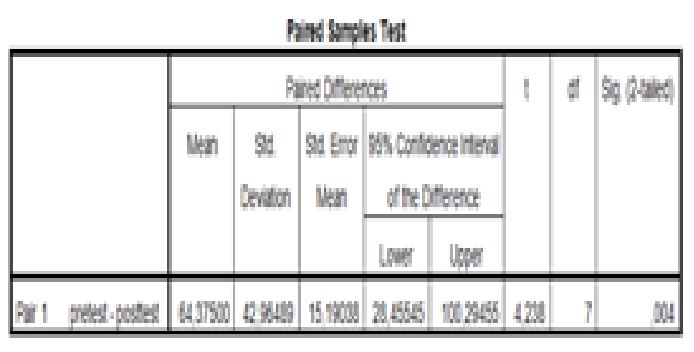

\section{Pembahasan}

Sebelum melakukan penelitian, Instalasi Kamar Operasi belum memiliki standar prosedur operasional manajemen waktu staf kamar operasi, namun peraturan waktu pelayanan operasional kamar operasi telah tertuang di kebijakan instalasi kamar operasi. Berdasarkan hasil 
FGD (focus group discussion) bersama pembimbing lapangan, kepala seksi pelayanan medis, ketua unit P2JK, dokter spesialis bedah umum dan sekertaris diklat RSU Karsa Husada, dipilih possible solution untuk dilaksanakan di Rumah Sakit Umum Karsa Husada adalah membuat standar prosedur operasional (SPO) mengenai manajemen waktu staf kamar operasi. Manajemen waktu staf kamar operasi adalah waktu yang dimulai dari pasien masuk kamar operasi hingga keluar ke ruang recovery. Selanjutnya, memberikan sosialisasi mengenai pentingnya SPO untuk dipatuhi agar jadwal operasi elektif berjalan sesuai dengan jadwal yang telah ditentukan dan tidak terjadi penundaan operasi. Setelah sosialisasi dan implementasi SPO dijalankan, peneliti melakukan analisis data primer serta data sekunder pre dan post sosialisasi.

Sosialisasi tentang standar prosedur operasional (SPO) manajemen waktu staf kamar operasi menunjukkan hasil yang cukup bermakna dengan peningkatan sebesar $25 \%$. perubahan yang didapatkan tidak begitu besar karena keterbatasan waktu pengambilan sampel post sosialisasi. Sebuah penelitian mengatakan, terdapat faktor-faktor yang mempengaruhi kurangnya kinerja surveilans disebuah rumah sakit meliputi kurangnya sosialisasi program kerja, belum ada dukungan manajemen rumah sakit, dan kurangnya pengawasan pimpinan 4 .

Sosialisasi merupakan suatu proses yang berperan penting dalam pembelajaran seseorang untuk dapat mempelajari pola hidup sesuai dengan nilai, norma, serta kebiasaan yang dijalankan didalam suatu masyarakat atau kelompok 5. Perlunya sosialisasi tentang standar prosedur operasional manajemen waktu staf kamar operasi ini diharapkan agar semua staf dapat memahami sepenuhnya tentang pentingnya manajemen waktu yang efisien.

Hasil analisis diagram fishbone menunjukkan hasil yang sesuai bahwa faktor yang sangat berpengaruh terhadap lamanya waktu tunggu operasi adalah dari faktor people, process, place, policy dan productivity. Beberapa buku manajemen mutu kesehatan disebutkan bahwa perbaikan berkesinambungan membutuhkan aksi yang berkesinambungan pula. Manajemen waktu yang baik maka akan berdampak besar bagi sistem pelayanan operasional kamar operasi. Peneliti menyarankan agar peraturan kamar operasi atau SPO yang disepakati bersama dijalankan dan dipatuhi demi meningkatkan mutu pelayanan instalasi kamar operasi.

\section{SIMPULAN}

Akar masalah penelitian ini adalah manajemen waktu staf OK dengan solusi terpilih untuk memecahkan akar masalah tersebut adalah membuat SPO manajemen waktu staf OK. Implementasi solusi terpilih dibandingkan antara pre dan post implementasi dengan hasil terdapat peningkatan sebesar $25 \%$. Hasil penelitian tersebut belum dapat menurunkan lama waktu tunggu operasi elektif di RSU Karsa Husada. Perlu dilakukan penelitian lebih lanjut agar dampak dari solusi penelitian ini dapat menurunkan lama waktu tunggu operasi elektif di RSU Karsa Husada.

\section{DAFTAR PUSTAKA}

1. Kurniadi A. 2011. Rancangan Optimasi Kontrol Pelayanan Di Instalasi Bedah Sentral Rumah Sakit Umum Daerah Tugurejo Semarang. Visikes.;10.

2. Denton, B., Viapiano, J., Vogl, A. 2007. Optimization of Surgery Sequencing and Scheduling Decisions Under Uncertainty, Health Care Management Science 10: 13-24.

3. Fei, H., Meskens, N., Chu, C., 2006. An Operating Theatre Planning And Scheduling Problem in The Case of a Block Scheduling Strategy, Proceedings of the International Conference on Service Systems and Service Management.

4. Lelonowati D, Koeswo M, Rokhmad K. 2014. Faktor Penyebab Kurangnya Kinerja Surveilans Infeksi Nosokomial di RSUD Dr.Iskak Tulungagung.

5. Pendidikanku. Pengertian Sosialisasi Menurut Para Ahli. (Online) 2015 http://www.pendidikanku.net/2015/07/pengertiansosialisasi.html (cited 2015 October 22). 